\title{
Examination and Use Tax Effects of Self Assessment Moderating Technology System in Hotel Tax Revenue in Denpasar
}

\author{
AA Sagung Ary Nur Arista \\ I Nyoman Wijana Asmara Putra \\ Master Program in Accounting, Udayana University, Jl. 80323 PB Sudirman Denpasar, Indonesia
}

\begin{abstract}
This study aimed to test tax audits and the use of technology moderating effect of self assessment system in hotel tax revenue. Hotel tax is a local tax has the largest proportion among other local taxes to increase revenue (PAD) in the city of Denpasar, therefore the hotel tax became a focus for many people that the hotel tax revenue is increasing every year. The study was conducted at the taxpayer in the city of Denpasar. Data were collected through a questionnaire technique. The method used to determine the number of samples in this study using purposive sampling. The data analysis technique used is the test Moderated Regression Analysis (MRA).The results showed that the first; self-assessment system has a positive effect on hotel tax revenue, second; examination weaken the influence of self-assessment tax system in hotel tax revenue, third; the use of technology cannot moderate the effect of self-assessment system in hotel tax revenue.
\end{abstract}

Keywords: tax audits, use of technology, self assessment system, hotel tax revenue

DOI: $10.7176 /$ RJFA/10-5-09

Publication date:March $31^{\text {st }} 2019$

\section{INTRODUCATION}

In the era of the current public sector reform at all levels of government bureaucracy required to be more adaptive and anticipatory of the changes that are and will happen. Changes in various aspects of the current carried by these reforms have led to diverse demands towards good governance (Asmadewa, 2006). Changes to the conditions sought for the implementation of responsible governance, in line with the principles of democracy, efficient and prevention of corruption, both political and administrative. Changes initiated from one of the reform agenda related to regional autonomy as stipulated in article 1, paragraph 5 of Law No. 32 of 2004 .

Autonomy granted to counties and municipalities conducted by authorizing local governments to regulate the area (Young and Dharsuky, 2015; Lopez et al., 2016 and Dalimunthe et al., 2016). The impact of regional autonomy is the growing amount of authority and responsibility given to the regions, to maximize the potential that exists (Laila et al., 2016). The increased authority and responsibility of local government in penyelenggaraa government in managing the optimal potential of the region itself, including in the management of the sources of local revenue (PAD) PAD is used to measure the ability and financial independence of a region (Nasir et al. 2017), The higher the proportion of revenue to the regional revenue in the budget, the better the level of financial independence and greater financial capacity of an area to finance the implementation of government tasks and development (Yahya, et al. 2017). Financing of regional autonomy that comes from local revenue (PAD) include local taxes and levies (Rooy and Novi, 2015). Generally, the majority of local revenue contributed by the local tax collection (Sitompul, et al. 2014), as well as several other local revenue sources, namely retribution, the results of which are separated regional wealth management and other legitimate local revenue. 2015). Generally, the majority of local revenue contributed by the local tax collection (Sitompul, et al. 2014), as well as several other local revenue sources, namely retribution, the results of which are separated regional wealth management and other legitimate local revenue. 2015). Generally, the majority of local revenue contributed by the local tax collection (Sitompul, et al. 2014), as well as several other local revenue sources, namely retribution, the results of which are separated regional wealth management and other legitimate local revenue.

Local tax component which has an important role as well as a very good prospect to be developed for the area of income tax and tax hotel restaurant (Jannah et al., 2016). Local taxes should be managed professionally and transparently in order to optimize and improve the business contribution to budget revenues and expenditures through intensification and extensification levied subjects and objects of local taxes.

The first factor that affects the quality of financial reporting is education. So the higher the level of education in the field of accounting easier to prepare financial statements. The accounting process in making a financial statement based on the principles and standards of preparation of financial statements that are applied in the Financial Accounting Standards Entities Without Public Accountability (SAK-ETAP). Financial Accounting Standards for Entities Without Public Accountability (SAK ETAP) is meant to be used entities without public accountability, such as SMEs. Prospects SAK ETAP implementation in SMEs requires an understanding of SAK ETAP.

Strong local revenue base is very important for the sustainability of the decentralization program (Karimi et 
al. 2017). Regional Revenue Agency Denpasar also has a duty to ensure that citizens pay their taxes at maturity (Hashidu, et al. 2017). The hotel tax has characteristics which the taxpayer is an individual or business entity in the field of hospitality being required to pay taxes on objects or any services given to the customers.

Increasing number of taxpayer this hotel will surely have an impact on increasing the income tax and levy, so it will be able to meet the revenue target area (Yuliandari, et al. 2017). Nevertheless, despite an increase in taxpayer in each year does not directly give a positive effect for local tax revenue. One of the factors which led to a reduction of the tax revenue this hotel is the application of the self assessment system.

Application of this self assessment system produces a large shift of responsibility to the taxpayers with regard to their compliance obligations. Additional responsibility for the taxpayer including the obligation to report, calculate and pay their taxes in accordance with tax laws (Sapiei and Kasipillai, 2013), so it can be interpreted that the taxpayer hotels decide the amount of taxes owed. The increasing levels of self assessment system applied by the taxpayer will have an impact on increasing tax revenues.

On the phenomenon can be concluded that the self-assessment system has an effect on tax revenue, it is supported by previous studies conducted by Trisnayanti and Teak (2015) and Ebimobowei and Gabriel (2014) which states that the self-assessment system a significant effect on tax revenues. The study is contrary to research conducted by Sitio (2015) and Maulida and Adnan (2017) which states that the self-assessment system does not affect the value-added tax revenue.

Based on research on the impact of exposure to the self assessment system of tax revenue is found the results varied hotel / inconsistent or still controversy suspected because of the other factors that affect the relationship between independent variables and the dependent variable. Govindarajan (1986) stated that the possibility of lack of unity of the results depends on certain factors, or better known as contingency factor. Murray (1990) explains that in order to reconcile the conflicting results contingency approach is needed to identify other variables which act as a moderating or pemediasi in research models. Conceptual and empirical research results,

Inspection is one way that the taxpayer remains outside in the hallway tax rules and tax authorities in performing their duties not only to the activities of formality, but also to strengthen the validity of the transaction and legal compliance with the laws in force in order to Taxpayers remain adherent to exercise their rights and tax obligations (Hidayat, 2005). The tax authorities made various efforts, both extension and intensification in increasing the amount of local tax revenue. Extending an effort to increase tax revenues by increasing the number of active taxpayer. While intensification pursued by increasing intensive tax audits that the tax revenue target could be achieved (Ardian and Dudi, 2015).

The government's efforts to increase tax revenues and reduce fraud in taxation through tax audits need to be adopted to monitor and detect non-compliance with the nature of the taxpayer / Taxpayer (Kazeem, 2016). The examination of this tax is one of law enforcement would have an impact on increasing the local tax revenue (Mandagi et al., 2014), it is supported by research Herryanto and Agus (2013) and Saad (2014) which states that the tax audit positive effect on tax revenue, It is also in line with research Bosco (2018) and Nwaiwu and Macgregor (2018) which concluded that the positive effect of tax audits on tax revenue. Therefore,

Other factors that can also affect the local tax revenue with the use of technology. Integrated information technology support is absolutely necessary in order to intensify the tax because the tax collection system is applied have tended not optimal (Aliudin, 2015). The use of this technology is done by the Regional Revenue Agency Denpasar to install recording devices transaction (tapping box). Tapping box that is a system that can monitor the online associated with all transactions made by taxpayers hotels. This online-based monitoring system is able to take the data transmitted from the cash register to the printer and then send it via the GSM network to the server Denpasar Regional Revenue Agency.

Activity tapping this box will result in an increase in local tax revenue, it is supported by research Mustapha, et al (2015) and Suardani et al. (2017) which states that the application of tapping box positive effect on tax revenue. On the basis of the description of various previous studies above, there are still gaps (inconsistencies) research (research gap) is different about the factors that affect tax revenues. So there are enough reasons for reviewing the tax assessment and the use of technology moderating influence on the self assessment system Denpasar City hotel tax revenue.

This study is a modification of a previous study conducted by Liana et al. (2017) and Ebimobowei and Gabriel (2014) by adopting the variable self assessment system and tax revenue. Differences of this study with previous research is to add the tax assessment and the use of technology as a moderating variable. The reason the addition of variable tax audits and the use of this technology, because of the tax audit is a control measure that is actively conducted by the tax authorities, while the use of technology is a control measure is passively conducted by the tax authorities through the online system, so that could be expected to moderate the relationship self assessment system in affecting tax revenue hotel.

Government Regulation No. 91 Year 2010 on Regional Taxes levied type based on the determination of the Regional Head or paid by the taxpayer, where such regulations regulate the types of taxes and payment by using 
the self-assessment system by the taxpayer. Self Assessment System have led to taxpayer get a heavy burden for all activities conducted fulfillment of tax obligations by the taxpayer himself (Siti Kurnia, 2010: 102).

Application of this self assessment system will determine the amount of taxes that will be accepted by the local government, it is in line with research conducted by Sadiq et al. (2015) and Harris and Sri (2016) to show that the self-assessment system a significant effect on tax revenues. Similar results were shown by Trisnayanti and Teak (2015) which states that the self-assessment system has a positive effect on tax revenue.

H1: Self-assessment system has a positive effect on tax revenue of the hotel.

Self-assessment systemthat in its implementation gives credence to the taxpayer to calculate, calculate, and report on their own pay taxes owed would be a liability, which in practice is difficult to walk as expected even abused (Tarjo and Indrawati, 2006). One of the fundamental things that must be done to support the successful implementation of self assessment system is to enforce the law (law enforcement) taxation. One form of the rule of law, through the presence of a tax audit for taxpayers (WP) that fail to meet tax obligations, in addition to this action is one implication of the theory of planned behavior that aims to provide assurance to taxpayers to be more submissive and obedient in paying and depositing the tax obligation.

Suharto (2010) menyatakkan that tax audits as a means to conduct oversight and guidance to the taxpayer, which has the objective to test the level of tax compliance in meeting tax obligations. The holding of examinations will increase taxpayer compliance which led to an increase of the existing tax revenue. However, the results of research conducted by Yeni (2013) and Prihastanti (2015) showed that the level of tax compliance and increase tax revenues, weakened by the existence of a tax audit as a moderating variable.

$\mathrm{H} 2$ : Examination of moderating influence of self-assessment tax system in hotel tax revenue.

Rahmany (2014) states that the responsibility for payment of tax liability as a reflection of the state obligations in the field of taxation that are in their own community members to meet those obligations. This is in accordance with the self-assessment system adopted in the taxation system in Indonesia, the implementation of self-assessment system in collecting taxes provide some risk of one of them is the fraud committed by the taxpayer in calculating and reporting tax (Suardani et al., 2017). Based on this it is necessary to monitoring or surveillance to the taxpayer to ensure fairness in the tax reporting.

In the process of implementation of the payment of the tax paid by the taxpayer (self-assessment) as set out in Article 4 of the Indonesian Government Regulation No. 91 Year 2010 About Type Local Taxes are uncollected Based Determination of Regional Head Or Paid Individual Taxpayer is necessary to supervise the reporting of Taxpayers business transaction data through the use of online technology known systems by tapping the box. The use of this online monitoring system if it is associated with the theory of planned behavior is the approach taken by the Revenue Agency of Denpasar in overseeing the taxpayer so that the taxpayer can be obedient in carrying out the self-assessment system. Taxpayer compliance in the self assessment system will have an impact on increasing tax revenues.

H3: The use of technology moderating effect of self assessment system in hotel tax revenue.

\section{BASIC THEORY}

\subsection{Attribution theory}

According to Weiner (1985), the attribution theory to study the process of how someone interprets an event, reason or cause behavior. Basically, the attribution theory states when individuals observing someone's behavior, they try to determine whether it is caused internally or externally (Robbins, 1996). Internally caused behavior is behavior that is believed to be under the personal control of the individual, whereas externally induced behavior is behavior that is influenced from the outside, meaning individuals will be forced to act because of the situation.

\subsection{Theory of Planned Behavior}

The theory of planned behavior (TPB) is an interest of individuals to perform certain behaviors, in the context of the adoption of information systems. Model theory of reasoned action has limitations. Limitations of this theory expressed by Jogiyanto (2007), which only describes the behaviors that will be done voluntarily, not for behaviors that are required. In this theory the wishes of behavior (behavioral intention) comprising: an attitude (attitude), subjective norms (subjective norms) and perceived behavioral control (perceivedbehavioral control).

\subsection{Tax revenue}

Tax revenue is earned income area imposed under the local regulations in accordance with the legislation. Local Tax is a tax set by local governments with local regulations (regulations), which authorized the collection is done by the local government and the results are used to fund government spending and development in the region (Maznawaty et al., 2015).

\subsection{Self Assessment System}

Self-assessment systemis a system of taxation which authorizes the taxpayer to decide for themselves the amount 
of taxes owed. Official (2014: 11) states in the self-assessment system of taxation success or failure depends on the taxpayer's own (no dominant role in the taxpayer).

\subsection{Tax audits}

Examination according to Article 1 (25) of Law No. 28 of 2007 concerning Third Amendment of Law No. 6 of 1983 on General Provisions and Tax Procedures is a series of activities to collect and process data, information, and / or evidence to be implemented objective and professional based on a standard of examination to test compliance of tax obligations fulfillment and / or for other purposes in order to implement the provisions of the tax legislation.

\subsection{Use of Technology}

The use of information technology in public administration used in the provision of better quality services to taxpayers, especially in the context of the governance of data is open (Canares, 2016). Use of information technology applied by the Regional Revenue Agency Denpasar namely transaction recording device (tapping box).

\section{METHODOLOGY}

This research was conducted in the city of Denpasar. The reason for choosing this location was because of the economic development in the city of Denpasar has increased the number of hotels so that the potential of the tax impact on a significant increase in tax revenues. The population in this study are all Taxpayer hotels listed in the income of the Regional Board of Denpasar until the year 2017. The sampling technique in this study using purposive sampling method, the sampling based on the consideration or criteria. As for the criteria for granting the tax payers hotel questionnaire conducted tax audits and the use of tapping box. So that the sample in this study amounted to 38 taxpayer hotels. Respondents in this study were the chief accounting of each hotel, the selection of chief accounting as research respondents because this position was responsible for coordinating the operational preparation of financial reports (monthly and annual) and cash flow planning the hotel. Analysis of the data used in this study was Moderating Regression Analysis (MRA). The regression model in this study is shown by the following equation.

Information :

$$
\mathrm{Y}=\mathrm{a}+\mathrm{b} 1 \mathrm{x} 1+\mathrm{b} 2 \mathrm{X} 2+\mathrm{b} 3 \mathrm{X} 3+\mathrm{b} 4 \mathrm{X} 1 \_\mathrm{X} 2+\mathrm{b} 5 \mathrm{X} 1 \_\mathrm{X} 3+\mathrm{e}
$$

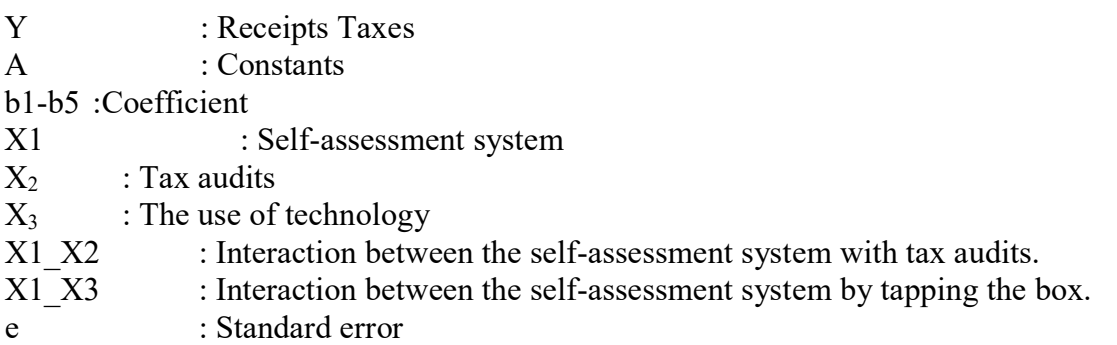

The dependent variable in this study is the tax revenue the hotel which is measured using indicators understanding of taxpayers regarding the provisions of tax legislation hotels, accuracy taxpayers to pay hotel taxes owed right on time, consciousness of taxpayers about the importance of paying taxes and own calculations required tax remitted to the tax (Irsan et al., 2016). The independent variable in this study is a self-assessment system, tax audits and the use of technology. Self-assessment system is measured with awareness of the taxpayer to register as a taxpayer, calculating withholding taxes, paying the tax owed and Reporting Notice (Friskianti, 2014). Measured by indicators such tax audit tax audit procedures, the attitude of the taxpayer to the tax inspection, apparat ability to tax authorities and the tax audit (Septya et al., 2016). The use of technology is measured by indicators taxpayer Knowledge of transaction recording device (tapping box), Role transaction recording device (tapping box) and taxpayer confidence in the transaction recording device (Regional Revenue Agency Denpaar, 2018).

\section{RESULTS AND DISCUSSION}

The minimum requirement to satisfy the validity of a questionnaire is if the correlation between the grains with a total score is positive and a value greater than 0.30 . The test results indicate that the validity of all of the variables have a correlation coefficient with the total score of the entire item statement greater than 0.30. 


\begin{tabular}{|c|c|c|c|}
\hline Variable & Indicator & Correlation coefficient & Information \\
\hline Self Assesment System & $\mathrm{X}_{1.1}$ & 0,897 & Valid \\
\hline \multirow{6}{*}{$\left(\mathrm{X}_{1}\right)$} & $\mathrm{X}_{1.2}$ & 0,855 & Valid \\
\hline & $\mathrm{X}_{1.3}$ & 0,879 & Valid \\
\hline & $\mathrm{X}_{1.4}$ & 0,940 & Valid \\
\hline & $\mathrm{X}_{1.5}$ & 0,907 & Valid \\
\hline & $\mathrm{X}_{1.6}$ & 0,925 & Valid \\
\hline & $\mathrm{X}_{1.7}$ & 0,907 & Valid \\
\hline \multirow[t]{6}{*}{ Tax audits $\left(\mathrm{X}_{2}\right)$} & $\mathrm{X}_{2.1}$ & 0,949 & Valid \\
\hline & $\mathrm{X}_{2.2}$ & 0,843 & Valid \\
\hline & $\mathrm{X}_{2.3}$ & 0,885 & Valid \\
\hline & $\mathrm{X}_{2.4}$ & 0,930 & Valid \\
\hline & $\mathrm{X}_{2.5}$ & 0,931 & Valid \\
\hline & $\mathrm{X}_{2.6}$ & 0,922 & Valid \\
\hline \multirow[t]{5}{*}{ technology use $\left(\mathrm{X}_{3}\right)$} & $\mathrm{X}_{3.1}$ & 0,926 & Valid \\
\hline & $\mathrm{X}_{3.2}$ & 0,876 & Valid \\
\hline & $\mathrm{X}_{3.3}$ & 0,912 & Valid \\
\hline & $\mathrm{X}_{3.4}$ & 0,937 & Valid \\
\hline & $\mathrm{X}_{3.5}$ & 0,878 & Valid \\
\hline \multirow[t]{6}{*}{ hotel tax receipt $(\mathrm{Y})$} & $\mathrm{Y}_{4.1}$ & 0,775 & Valid \\
\hline & $\mathrm{Y}_{4.2}$ & 0,832 & Valid \\
\hline & $\mathrm{Y}_{4.3}$ & 0,788 & Valid \\
\hline & $\mathrm{Y}_{4.4}$ & 0,828 & Valid \\
\hline & $Y_{4.5}$ & 0,828 & Valid \\
\hline & $Y_{4.6}$ & 0,901 & Valid \\
\hline
\end{tabular}

Source: SPSS though, 2019

The validity of the test results presented in Table 1 indicate that all variables have a correlation coefficient with the total score of the entire item statement greater than 0.30 .

Reliability Test is the degree of accuracy, precision or accuracy demonstrated through measurement instruments, testing can be done internally, testing by analyzing the consistency of the existing grains. The instrument can be said to be reliable if such instrument had a Cronbach alpha value of more than 0.60.

Table 2 Results of Test Reliability

\begin{tabular}{clcc}
\hline No. & \multicolumn{1}{c}{ variables } & Cronbach's Alpha & Information \\
\hline 1 & Self Assessment System (X1) & 0.961 & reliable \\
2 & Tax Inspection (X2) & 0,959 & reliable \\
3 & Use of Technology (X3) & 0.945 & reliable \\
4 & Receipts Taxes (Y) & 0.907 & reliable \\
\hline
\end{tabular}

Source: SPSS though, 2019

Reliability test results are presented in Table 2 indicate that all instruments used in this research has a Cronbach's Alpha coefficient of more than 0.60.

Descriptive statistical analysis provides a picture or description of the data seen from the minimum value, maximum, mean, and standard deviation (standard deviation) and $\mathrm{N}$ is the number of respondents. Results of descriptive statistical analysis are shown in Table 3.

Table 3 Descriptive Statistics

\begin{tabular}{lccccc}
\hline & N & Min. & Max. & mean & Category \\
\hline Self Assessment System (X1) & 38 & 8.26 & 33.50 & 27.8845 & High \\
Tax Inspection (X2) & 38 & 7.33 & 22.38 & 17.3447 & High \\
Use of Technology (X3) & 38 & 5.00 & 18,19 & 14.2958 & High \\
Receipts Taxes (Y) & 38 & 6.00 & 23.37 & 7.3466 & High \\
\hline
\end{tabular}

Source: SPSS though, 2019

The minimum value of the total score of respondents to the variable Self Assessment System (X1) of 8.26 and a high of 33.50. A middle value (mean) of the number of respondents score amounted to 27.8845 , then the respondents can be categorized as high. This shows hotel taxpayer behavior of high self assessment system.

The minimum value of the total score of respondents to the variable Tax Inspection (X2) of 7.33 and a high of 22.38. A middle value (mean) of the number of respondents score amounted to 17.3447 , then the respondents can be categorized as high. This shows the taxpayer the hotel has a high confidence against the tax authorities of tax inspection. 
The minimum value of the total score of respondents to the variable use of technology (X3) of 5.00 and a high of 18.19. A middle value (mean) of the number of respondents score amounted to 14.2958, then the respondents can be categorized as high. This shows the taxpayer the hotel has a high confidence on the use of technology.

The minimum value of the total score of respondents for hotel tax revenue variable (Y) of 6.00 and a high of 23.37. A middle value (mean) of the number of respondents score of 7.3466, then the respondents can be categorized as high. It shows taxpayer compliance tow hotel has to pay hotel taxes so as to increase the hotel tax revenue.

This test aims to determine whether the residuals from a regression model that made normal distribution or tidak.Untuk data used to test whether normal or can not be done using the Kolmogorov Sminarnov. If the coefficient Asymp. Sig. (2-tailed) is greater than 0.05 then the data is said to be normally distributed.

\begin{tabular}{cc}
\hline Residual unstandardized & \\
\hline N & 38 \\
Kolmogorov-Smirnov Z & 0.166 \\
Asymp.Sig. (2-tailed) & .200 \\
\hline
\end{tabular}

Source: SPSS though, 2019

Based on Table 5, the value of Kolmogorov Sminarnov (KS) is 0.108 , while the value of Asymp.Sig. (2tailed) is equal 0,087.Hasil indicates that the regression model are normal distribution for the value Asymp. Sig. (2-tailed) 0.200 greater than the alpha value of 0.05 .

The existence of multicollinearity can be seen from the value of tolerance or variance inflation factor (VIF). If the tolerance value is more than $10 \%$ or VIFKurang of 10 , then the value it can be said there is no multikolinearitas.Uji Multicolinearity can be seen in Table 6.

Table 6 Test Results Multikoleniaritas

\begin{tabular}{lcc}
\hline variables & tolerance & VIF \\
\hline Self Assessment System & 0,282 & 3,544 \\
\hline Tax audits & 0.395 & 2.535 \\
\hline Use of Technology & .352 & 2.841 \\
Pajak_Self examination Assessment System & 0.373 & 2,681 \\
Use of Teknologi_Self Assessment System & 0.163 & 6,146 \\
\hline
\end{tabular}

Source: SPSS though, 2019

Based on Table 6, tolerance and VIF value of each variable has a value tolerancemasing each for each variable is greater than $10 \%$ and VIF less than 10 , this means that the regression model is free from multicollinearity.

Heteroscedasticity test conducted to determine whether inequalities occur in the model regresi.Uji variants can be analyzed through the glacier test by looking at the level of significance, if the significance level is above 0.05 , the regression model is free of problems heterokedastisitas.

Table 7 Test Results Heteroskidastity

\begin{tabular}{lcc}
\hline variables & Value Sig. & Information \\
\hline Self Assessment System & .777 & Non heteroskedastisitas \\
Tax audits & 0.755 & Non heteroskedastisitas \\
Use of Technology & 0,745 & Non heteroskedastisitas Non \\
Pajak_Self examination Assessment System & 0,249 & heteroskedastisitas Non \\
Use of Teknologi_Self Assessment System & 0.254 & heteroskedastisitas
\end{tabular}

Source: SPSS though, 2019

In Table 7 it can be seen that the sig. of variable levels of education and individual The characteristics of each variable of greater than 0.05 means that there is no influence of independent variables on the absolute residuals. Thus, the model created does not contain has heteroscedasticity.

The feasibility of the model in this study viewed from sig. If the ANOVA table Sig. $<0.05$, the analysis model is considered feasible. If sig. $>0.05$, the analysis model is not feasible.

Table 8 Results of Feasibility Model (Test F)

\begin{tabular}{|c|c|c|c|c|c|c|}
\hline \multirow[b]{2}{*}{1} & \multirow{2}{*}{$\begin{array}{l}\text { Model } \\
\text { Regression }\end{array}$} & \multirow{2}{*}{$\begin{array}{r}\text { Sum of Squares } D \\
660.050\end{array}$} & \multicolumn{2}{|c|}{ mean Square } & \multicolumn{2}{|c|}{$\begin{array}{ll}\text { F } & \text { Sig. }\end{array}$} \\
\hline & & & 5 & 132.010 & 17.048 & 0,000 \\
\hline & residual & 247.787 & 32 & 7.743 & & \\
\hline & Total & 907.837 & 37 & & & \\
\hline
\end{tabular}

Source: SPSS though, 2019

Results Anova or ( $\mathrm{F}$ test) in Table 8 shows the results of the feasibility test models indicate the tax assessment and the use of technology to significantly moderate the influence of the self-assessment system on 
the tax revenues hotel, where significant F 0,000 less than 0,005 so it can be concluded that this research model be feasible to study and hypothesis verification can proceed.

The value of the coefficient of determination in the logistic regression model indicated by R Square. Results of can be seen in Table 9 .

Table 9 Test Results The coefficient of determination (R2)

\begin{tabular}{cccccrr}
\hline Model & R & \multicolumn{2}{c}{ R Square } & Adjusted R Square & \multicolumn{2}{c}{ Error of the Estimate } \\
\hline 1 & & .853 & 0.727 & & .684 & 2.78269 \\
\hline
\end{tabular}

Source: SPSS though, 2019

Based on Table 9 adjusted $\mathrm{R}^{2}$ is 0,684 or 68,4 percent, this means that amounted to 68,4 percent hotel tax revenue variation influenced by the model established by self-assessment system (X1), the tax audit (X2), the use of technology (X3), self assessment system interaction with tax audits ( X1_X3) and the interaction of self assessment system with the use of technology (X2_X3), while the remaining 31,6 percent is explained by other factors not described in this study.

The results of multiple linear regression tests can be seen in Table 10.

Table 10 Results of Multiple Linear Regression Analysis

\begin{tabular}{|c|c|c|c|c|c|}
\hline \multirow[t]{2}{*}{ Model } & \multicolumn{2}{|c|}{ Coefficients unstandardized } & \multirow{2}{*}{$\begin{array}{l}\text { standardized } \\
\text { coefficients } \\
\text { Beta }\end{array}$} & \multicolumn{2}{|r|}{ Sig. } \\
\hline & B & Std. Error & & & \\
\hline (Constant) & -15.754 & 7.498 & 1,101 & -2.101 & 0,044 \\
\hline $\mathrm{X} 1$ & .864 & .329 & 1,379 & 2,629 & 0,013 \\
\hline $\mathrm{X} 2$ & 1.251 & 0.464 & .551 & 2,694 & 0,011 \\
\hline X3 & .603 & .639 & -1.704 & 0.944 & .352 \\
\hline $\mathrm{X} 1 \_\mathrm{X} 2$ & -0.038 & 0,017 & -0.209 & -2.272 & 0,030 \\
\hline $\mathrm{X} 1 \mathrm{X} 3$ & -0.006 & 0,023 & & -0.239 & 0,813 \\
\hline
\end{tabular}

Source: SPSS though, 2019

Based on test results hipoteis the first hypothesis stating a self-assessment systempositive impact on hotel tax revenue received. Hypothesis 2 stated tax audit moderate the relationshipself assessment systemin hotel tax revenue received. While the third hypothesis which states the use of technology moderates the relationshipself assessment system in hotel tax revenue declined.

\section{The Effect of Self Assessment System on Hotel Tax Receipts}

The test results obtained empirical evidence that $\mathrm{H} 1$ is supported by a positive coefficient. This means that the higher the self assessment system behavior, the hotel tax revenue increases. The results of this study are consistent with the research conducted by Sadiq et al. (2015), Harris et al. (2016) and Trisnayanti and Jati (2015). Several studies that have been conducted have obtained empirical evidence that the behavior of the self assessment system has a positive effect on hotel tax receipts. In the fully self-assessment system of authority to determine taxation is on taxpayers (Rahayu, 2017: 101).

Tax Examination Moderates the Effect of the Self Assessment System on Hotel Tax Receipt

The test results obtained empirical evidence that $\mathrm{H} 2$ was supported. This means that tax audits weaken the influence of the self assessment system on hotel tax receipts. The results of this study do not support the theory of Waluyo and B (2011: 65) which states that tax audit as a means of testing the level of tax compliance in fulfilling its tax obligations, so that this tax audit will increase taxpayer compliance which will also have an impact on increasing revenue tax. However, the results of this study support Prihastanti's (2015) research by showing that the level of taxpayer compliance and increasing tax revenues are weakened by the existence of tax audits as a moderating variable. Higher tax audit causes many hotel taxpayers to object to the results of the tax audit. Objections made by hotel taxpayers on the results of examinations indicate that hotel taxpayers do not have awareness and obedience in carrying out self assessment system actions, the reason for hotel taxpayers who object to the results of this examination is due to differences in tax calculation results that should be paid between tax with the tax authorities. Even though the results of examinations carried out by the tax authorities are in accordance with the evidence found in the field, this cannot provide assurance to the hotel taxpayers being inspected so that hotel taxpayers do not have normative beliefs on the objective attitude of the tax authorities in conducting tax audits.

Use of Technology Moderating the Self Assessment System at Hotel Tax Receipts

The test results obtained empirical evidence that $\mathrm{H} 3$ is not supported. This means that the use of technology does not affect the level of influence of the self assessment system variable on the hotel tax receipt variable. Thus it can be concluded that the use of technology does not strengthen or weaken the influence of the self assessment system on hotel tax receipts. The results of this study do not support the Theory of Planned Behavior theory, namely Control Beliefs which are individual beliefs about the existence of things that support or hinder their behavior and their perceptions of how strongly these things affect their behavior. The attitude of hotel taxpayers 
who do not have control beliefs on the use of technology through the application of tapping boxes, as a hotel taxpayer, is not yet certain that the tapping box can record the entire transaction correctly and real-time. This is evidenced by the answers of several hotel taxpayer respondents who disagree with question X3.4 stating that the use of technology through the application of tapping boxes will be able to record all transactions in real time.

\section{CONCLUSION}

Self-assessment systempositive effect on tax revenue of the hotel. This means the behavior of self-assessment system of the taxpayer that the higher the hotel will increasingly affect both the hotel tax revenue. Tax Inspection weaken the influence of the self-assessment system in hotel tax revenue. This means that a high tax audit will weaken the self assessment system undertaken by the taxpayer hotel, so the hotel tax revenue will decrease. The use of technology does not moderate the influence of self-assessment system in hotel tax revenue. This means that the use of technology does not weaken or strengthen the self-assessment system in hotel tax revenue.

\section{References}

Aliudin. 2015. Optimization And Estimated Tax Restaurant To Increasing Performance Development Areas In The City Serang, Banten Province, Indonesia. International Journal of Information Research and Review, 2 (8), pp. 1011-1015.

Ardian, Raden Devri., And Dudi, Pratomo. 2015. Influence of Tax System and Tax Investigation Against Tax Evasion (Tax Evasion) By Taxpayer (Studies in Kpp Pratama Bandung Region). e-Proceedings of Management, 2 (3), p: 3169-3178.

Asmadewa, I. 2006. Factors Affecting Implementation Effectiveness Performance-Based Budgeting (Survey on Central Government). Thesis UGM. Yogyakarta.

Bosco, Jean. 2018. Effect of Tax Audit on Revenue Collection in Rwanda. Global Journal of Management and Business Research: Accounting and Auditing, 18 (2), pp: 1-11.

Canares, Michael P. 2016. Creating the Enabling Environment for More Transparent and Betterresourced Local Governments: A Case of E-taxation in the Philippines. Information Technology or Development, 22 (1), pp: $121-138$

Dalimunthe and Young. 2016. The application of performance measurement system models using the Malcolm Baldrige Model (MBM) to support Civil Law State Apparatus (ASN). International Journal of Applied Business and Economic Research, 14 (11), pp: 7397-7407.

Ebimobowei, Appah and Gabriel, Ogbonna. 2014. Self-Assessment Scheme And Revenue Generation In Nigeria. Developing Country Studies, 4 (10), pp: 102-111.

Friskianti, Yossi. 2014. Influence of Self Assessment System, Justice, Taxation Technology, and distrust of the people at the tax authorities Measures Against Tax Evasion. Accounting Analysis Journal, 3 (4), p. 543-552

Govindarajan, V. 1986. Impact Of Participation In The budgetary Process Management On Attitudes And Performance: Universalistic And contingency Perspectives. Decision Sciences. pp. 496 -516.

Harris, Topowijono and Sri Sulasmiyati. 2016. Influence of Self Assessment System and Inspection of Taxes on Income Tax Revenue (Income) (Study on the Tax Office Municipality of Malang Period 2012-2014). Journal of Taxation (TRACES), 8 (1), pp: 1-6.

Hashidu, Shehu, Umar Adamu., And Usman Isah. 2017. An Assessment Of Factors That Influence Taxation; Taxpayers And The Self Employed In Nigeria. International Journal of Social Sciences and Humanities Reviews, 7 (2), pp: 194-202.

Herryanto, Marisa and Arianto, Agus. 2013. Influence Taxpayer Awareness, Socialization of Taxation and Tax Investigation Against Income Tax Receipts In the Primary Kpp Sawahan Surabaya. Tax \& Accounting Review, 1 (1), pp: 125-135.

Hidayat Nur. 2005. Priority in Tax Inspection. Faculty of Economics. Bandung: Maranatha Christian University.

Irsan., Ali, Hidayat., Kadarisman, Maria. 2016. Effect of Taxpayer Compliance Hotels And Restaurants Against Local Tax Revenue (Studies in the Department of Revenue Malang). Journal of Taxation (TRACES), 8 (1), p. 1-7.

Jannah., Suyadi., And Utami. 2016. Contributions Against Local Tax revenue (Studies in Mojokerto regency Revenue Service). Journal of Taxation (TRACES), 10 (1), p. 1-8.

Karimi, Harriet., Kenya, Kimani., Maina, Lecturer., Kenya, Jesse., And Maina, Kinyua. 2017. Effect Of Technology And Information Systems On Revenue Collection By The County Government Of Embu, Kenya. International Academic Journal of Information Systems and Technology, 2 (1), pp: 19-35.

Kazeem, Soyinka., Jinadu, Olugbenga., Sunday., And Oluwafemi, Michael. 2016. Determinants Tax Audit and Corporate Tax Compliance in Nigeria. The International Journal of Business \& Management, 4 (5), pp: 95 99.

Laila, Hamida El., Eka Nur Jannah., Imam, Suyadi., And Hamida, Nayati Utami. 2016. Contributions Against Local Tax revenue (Studies in Mojokerto regency Revenue Service). Journal of Taxation (trail), 10 (1), Hal: 
$1-8$.

Liana, Dewi., Gede, Diatmika., And son, Yasa. 2017. Effect of total tourist arrivals, Application of Self Assessment System, Billing And Taxes With Tax Revenue Warning Letter Of Hotels In Buleleng. EJournal Ganesha University of Education, 8 (2).

Maulida, Inayatul and Adnan. 2017. Influence of Self Assessment System, Tax Audit, and Tax Collection Against Acceptance of Value Added Tax (VAT) on STO Banda Aceh. Student Science Journal Economic Accounting (Jimeka), 2 (4), Hal: 67-74.

Maznawaty, Elvi Syahria. Ventje, physical defect and Inggriani, Elim. 2015. Analysis of Local Tax Revenue Increases Local Revenue In North Maluku province. EMBA Journal, 3 (3), Hal: 906-915.

Young, I and Abykusno Dharsuky. (2015), Impact of Region Financial Information System (MoF) Quality, role ambiguity And Training on Precision of Financial Statement Presentation of Local Government In North Sumatra. International Journal of Applied Business and Economic Research, 13 (6), pp: 4283-4304.

Mustapha, Bojuwon and Normala, Siti. 2015. Tax Service Quality: The mediating Effect of Perceived Ease of Use of the Online Tax System. Procedia - Social and Behavioral Sciences, 172, pp: 2-9.

Murray, D. 1990. The Performance Effects of participative budgeting, an Interpretation of intervening and Moderating Variables. Behavioral Research in Accounting, Vol. 2, pp.104-123.

Nasir, Azwir., Yesi Mutia., Kamaliah., And Iskandar Muda. 2017. Effectiveness of Potential Tax Region as the Real Local Revenue Sources in Riau Coastal Area. International Journal of Economic Research, 14 (12), pp: 313-324.

Nwaiwu and Macgregor. Webometric 2018. Indices Of Tax Audit And Tax Revenue Generation Research In Nige. International Journal of Advanced Academic Research, 4 (2), pp: 33-54.

Prihastanti, Rosy., Kiswanto. 2015 Level of Compliance Taxpayers Against Tax Receipts Moderated By Tax Inspection. Accounting Analysis Journal, 4 (1), Hal: 1-9

Officially, Siti. 2014. Taxation Theory and Case. Jakarta: Four Salemba.

Rooy, Freddy De and Novi, Budiarso. 2015. Analysis of Local Tax Revenue Contributions Toward revenue (Pad) in Raja Ampat. EMBA Journal, 3 (4), Hal: 451-461.

Saad, Natrah. 2014. Knowledge Tax, Tax Compliance and Tax Complexity: Taxpayers' View. Social and Behavioral Sciences, 109, pp: 1069-1075.

Sadiq, Melisa., Heroine, Kumadji., And Achmad, Husaini. 2015. Influence of Self Assessment System on the Value Added Tax Receipts (Study on STO Singosari Malang). Journal of Taxation (TRACES), 7 (1), pp: 15.

Sapiei, Sharoja., And Jeyapalan, Kasipillai. 2013. Impacts of the Self-Assessment System for Corporate Taxpayers. American Journal of Economics, 3 (2), pp: 75-81.

Septya., Devi, Mochammad, Dwiatmanto. 2016. Effectiveness of Tax Investigation In Order To Increase Tax Revenues (A Study on the Tax Office Pratama Malang Selatan). Journal of Taxation (TRACES), 8 (1), p. 19

Sitio, Rohmasari. 2015. Influence of Self Assessment System, Issuance of Tax Collection and Tax Collection Letter Forced to Value Added Tax Receipts in KPP Madya Pekanbaru Handsome STO dam. FEKON. 2 (2).

Suardani, Riska., Purnamawati, Ayu., And Kurniawan, Sukma. 2017. Monitoring the Effectiveness of Local Tax Information System Based On Hospitality Industry In Buleleng, S1 Accounting Department, 8 (2).

Suharto, Rudy and Ilyas wirawan B. 2010. Encyclopedia Indonesian taxation. Jakarta: Four Salemba

Tarjo and Indra Kusumawati. 2006. Behavioral Analysis Individual Taxpayer Against Self Assessment System Implementation: In A Bangkalan. JAAI, 10 (1), pp: 102-103.

Trisnayanti, Ida Ayu Ivon and Teak, I Ketut. Pengatuh 2015. Self Assessment System, Tax Audit and Tax Collection On Acceptance of Value Added Tax (VAT). ISSN: 2302- 8556. E-Journal of Accounting, University of Udayana, 13 (1), pp: 292-310.

Weiner, Bernard.1985. An Attributional Theory of Achievement Motivation and Emotion. Psychological Review, 92 (4), pp. 548-573.

Yahya., Torong., And Young. 2017. Influence Behavior in Legislature Budget Development of Regions in the Province of Aceh and North Sumatra. International Journal of Economic Research. 14 (8), pp: 147-159.

Yeni, Rahma. 2013. Effect of Compliance Taxpayers Against Increased Tax Revenue Moderated By Kpp Pratama Tax Audit In Padang. Essay. Padang State University.

Yuliandari, Rini., Taufik Chaidir., And Hadi Mahmudi. 2017. The Analysis of Effectivity and Efficiency of Tax Collection from Hotels and Restaurants in Order to Increase the Original Regional Income (PAD) in Mataram. Journal of Economics and Development Studies, 9 (2), pp: 251 -256 